\title{
乳兒ノ抗「ヂフテリー」先天性免疫二就テ
}

\author{
（昭和 11 年 7 月 11 日受附）
}

東大傳染病研究所檢查部(主任 小岛博士) =於テ

醫學博士 真 柄 正 直

$$
\text { 小豆畑 久治 }
$$

\section{第三編 新座兒。乳兒。裖婦及妊婦二於ケル}

\section{「シック」反應ノ葿義}

Schick$^{(24)}$ ガ稀釋セル「ヂフテリ一」毒素き皮內二注射シ. 其ノ後ノ反應き檢スルコト ニョリ感染防禦ニ必要ナル「ヂフテリ一」抗毒素ノ有無キ知り得ル方法キ發見シテョリ そョ「シック」ノ反應卜唱へ、極メテ多數ノ人身二就テ極メテ多數ノ追試ガ行ハレタリ。 而シテ Michielis \& Schick(13) ハ1/30 單位以上ノ抗毒素キ有スル者二於テハ本反應八 陰性ナリト云ヒ.Kolmer \& Moshage ${ }^{(15)}$ モ同樣ノ結果キ認メタリ。然レドモGröer \& Kassowitz ${ }^{(8)}$ 等, 成績ニヨレバ. 生後約 1 ケ年, 孚兒二於テハソノ血液中二抗毒素ョ 有七ザル者ニモ本反應八陰性トナルコト多ク．又7歲以上ノ者二於テハ Paradoxereaktion ノ現ハレルモノ多ク.郎チ抗毒素タ有スルニ拘ラズ本反應陽性トナルモノア リ。從ツテ「シック」反應ハ生後約 1 ケ年後ヨリ 7 ケ年ノ間二於テノ $i$ 殆ンド完全二信 賴シ得ルモノナリト云フ。

(附記. 書物ニヨリテ Paradoxereaktion トPseudoreaktion トォ同一ノ如ク扱フ モノアルモ余等ハ之キ區別シテ使用スルコト、セリ。郎チ Paradoxereaktion一矛盾 反應一ト八血液中二比較的多量, 抗毒素尹有スルニ拘ラズ「シック」反應陽性トナルモ ノチ云ヒ Pseudoreaktion一疑似反應一トハ「デフテリ一」毒素ニ對スル反應ニ非ズシ テ本毒素ヨ加熱破壞セル後ニ於テモ現ハル、モノタ云フコト、セリ。

\section{菑驗 方 法}

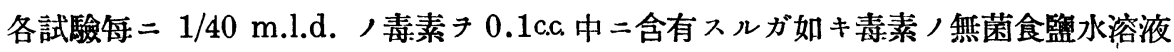

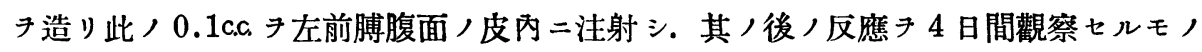
ナリ。對照トシテ此ノ毒素液ヨ $80^{\circ} \mathrm{C}=1$ 時間加熱セルモノ $0.1 \mathrm{c} . \mathrm{c}$ チ右前膊腹面!皮 
內二注射シテ左前膊ノモノト比較觀察セリ。

「ショク」反應陽性トハ.A）左ノミ二發赤腫脹キ生ジ右八不變ナルモノ及ビ左. 右共 二發赤來スモ左八右二比シテ大ニシテ而モ腫脹著シク. 又左ノ反鷹. 右ノモノ二比 シテ永ク存續スルモノ、二ナリ。

「シック」反應陰性ト八Ａ）左．右共二全ク反應ナキモノ及ビ B) 左. 右共二早期 二略了同等,發赤來スモ比較的速二褪色スルモノ、二ナリ。而シテ右前膊二郎于加 熱毒素ニョリテ發赤テ來セルモノフ疑似反應陽性トナシタリ。

\section{第一章 新産兒ニ於ヶル「シック」反應}

第 1 表二示スガ如ク 100 例二就テ.母兒ノ血液中ノ抗毒素キ定量スルト同時二之二 「ショク」反應タ施行七ル結果. 兒二於テハ其ノ血液中ノ抗毒素量 0.005 單位以上ノモ ノ 81 例八刎論悉ク本反應陰性ニシテ 0.005 單位以下ナルモノ 19 例二對シ僅カ $=4$ 例 ノそガ本反應陽性ナリシニ過ギズ。斯クノ如ク新產兒ニアリテハ「シック」應八極メテ 現ハレ難キモノニシテ其ノ血液中二殆ンド抗毒素き缺クト見ル心゙キモノニ於テモ本反 應八大部分陰性トナルモノナリ。從ツテ新產兒二於テハ「シ,ク」反應ハ其/血液中二 有スル抗毒素量き現ハス目標トナリ得ザルモノナリ。

又新產兒二於テハ「シック、反應ノそナラズ、疑似反應モ1例ニ於テモ之ナ見ザリキ。

第 1 表

\begin{tabular}{|c|c|c|c|c|c|c|c|c|c|c|c|c|c|}
\hline $\begin{array}{l}\text { 番 } \\
\text { 號 }\end{array}$ & $\begin{array}{l}\text { 姓 } \\
\text { 名 }\end{array}$ & $\begin{array}{l}\text { 年 } \\
\text { 龄 }\end{array}$ & 舟, & $\begin{array}{l}\text { 沉 } \\
\text { n 隹 }\end{array}$ & $\begin{array}{l}\text { 疑反 } \\
\text { 似應 }\end{array}$ & $\begin{array}{c}\text { 血清中) } \\
\text { 抗䓯素 } \\
\text { (單位) }\end{array}$ & $\begin{array}{c}\text { 番 } \\
\text { 號 }\end{array}$ & $\begin{array}{l}\text { 﨡 } \\
\text { 名 }\end{array}$ & $\begin{array}{l}\text { 年 } \\
\text { 跲 }\end{array}$ & 舟一 & 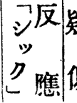 & 疑反 & $\begin{array}{l}\text { 血清中) } \\
\text { 抗毒素量 } \\
\text { (單位) }\end{array}$ \\
\hline & & \multirow{2}{*}{32} & 母 & -1 & & $\leftarrow 0.02$ & & & \multirow{2}{*}{23} & 母 & - & & 0.16 \\
\hline & & & 兒 & - & & 0.02 & & & & 兒 & - & & 0.32 \\
\hline \multirow{2}{*}{2} & & \multirow{2}{*}{24} & 母 & + & & $\leftarrow 0.02$ & & & \multirow{2}{*}{25} & 舟 & - & & 0.16 \\
\hline & & & 兒 & - & & $\leftarrow 0.02$ & & & & 兒 & - & & $0.16 \rightarrow \leftarrow 0.32$ \\
\hline \multirow{2}{*}{3} & & \multirow{2}{*}{31} & 母 & - & & 0.16 & \multirow[b]{2}{*}{10} & & \multirow{2}{*}{29} & 母 & - & & 0.64 \\
\hline & & & 兒 & - & & 0.32 & & & & 兒 & - & & 1.28 \\
\hline \multirow{2}{*}{4} & & \multirow{2}{*}{31} & 母 & - & & 0.16 & \multirow{2}{*}{11} & & \multirow{2}{*}{25} & 母 & - & & 0.04 \\
\hline & & & 兒 & - & & 0.32 & & & & 兒 & - & & 0.08 \\
\hline \multirow{2}{*}{5} & & \multirow{2}{*}{35} & 母 & - & & 0.32 & \multirow{2}{*}{12} & & \multirow{2}{*}{29} & 母 & - & & 0.04 \\
\hline & & & 兒 & - & & 0.64 & & & & 兒 & - & & 0.08 \\
\hline & & \multirow{2}{*}{28} & 母 & + & & $\leftarrow 0.02$ & \multirow{2}{*}{13} & & \multirow{2}{*}{26} & 母 & - & & $0.64 \rightarrow \leftarrow 1.28$ \\
\hline & & & 兒 & + & & $\leftarrow 0.02$ & & & & 兒 & - & & 1.28 \\
\hline & & \multirow{2}{*}{27} & 母 & - & & $0.04 \rightarrow \leftarrow 0.08$ & \multirow{2}{*}{14} & & & 母 & - & & 0.64 \\
\hline & & & 兒 & - & & $\mid \overline{0.08 \rightarrow \leftarrow 0.16}$ & & & & 兒 & $=$ & & 0.64 \\
\hline
\end{tabular}




\begin{tabular}{|c|c|c|c|c|c|c|c|c|c|c|}
\hline \multirow{2}{*}{15} & \multirow{2}{*}{29} & 册 & - & $\leftarrow 0.02$ & \multirow{2}{*}{37} & \multirow{2}{*}{24} & \multirow{2}{*}{ 兒 } & \multirow{2}{*}{$\frac{\mathrm{H}}{+}$} & & \multirow{2}{*}{$\begin{array}{l}\leftarrow 0.0025 \\
\leftarrow 0.0025\end{array}$} \\
\hline & & 兒 & - & 0.02 & & & & & & \\
\hline \multirow{2}{*}{16} & \multirow{2}{*}{29} & 母 & - & 0.16 & \multirow{2}{*}{38} & \multirow{2}{*}{29} & 母 & $\mathrm{H}$ & & $\leftarrow 0.0025$ \\
\hline & & 兒 & - & 0.32 & & & 兒 & + & & $\leftarrow 0.0025$ \\
\hline \multirow{2}{*}{17} & \multirow{2}{*}{24} & 母 & - & 0.08 & \multirow{2}{*}{39} & \multirow{2}{*}{28} & 母 & - & & $0.32 \rightarrow$ \\
\hline & & 兒 & - & $0.08 \rightarrow \leftarrow 0.16$ & & & 兒 & - & & $\leftarrow 0.64$ \\
\hline \multirow{2}{*}{18} & \multirow{2}{*}{24} & 母 & - & $0.16 \rightarrow \leftarrow 0.32$ & \multirow{2}{*}{40} & \multirow{2}{*}{24} & 母 & + & & $\leftarrow 0.0025$ \\
\hline & & 兒 & - & 0.64 & & & 兒 & - & & $\leftarrow 0.0025$ \\
\hline \multirow{2}{*}{19} & \multirow{2}{*}{36} & 母 & - & 1.28 & \multirow{2}{*}{41} & & 母 & - & & 1.28 \\
\hline & & 兒 & - & 1.28 & & 31 & 兒 & - & & $1.28 \rightarrow$ \\
\hline 20 & 26 & 母 & - & $1.28 \rightarrow \leftarrow 2.56$ & 42 & 20 & 母 & + & & $\leftarrow 0.0025$ \\
\hline & $2 \mathbf{b}$ & 兒 & - & $2.56 \rightarrow \leftarrow 5.12$ & 42 & & 兒 & \pm & & $\leftarrow 0.0025$ \\
\hline 21 & 26 & 母 & - & $0.08 \rightarrow \leftarrow 0.16$ & 43 & 26 & 母 & - & $+t$ & 0.16 \\
\hline & & 兒 & - & $0.16 \rightarrow \leftarrow 0.32$ & & & 兒 & - & - & 0.32 \\
\hline 22 & 32 & 母 & - & $\leftarrow 0.005$ & 44 & 24 & 母 & - & $t+$ & $\leftarrow 0.08$ \\
\hline & & 兒 & - & 0.005 & & & 兒 & - & - & $\leftarrow 0.16$ \\
\hline 23 & 26 & 母 & - & 2.56 & 45 & 24 & 母 & - & - & $0.16 \rightarrow$ \\
\hline & & 兒 & - & $2.56 \rightarrow \leftarrow 5.12$ & & & 兒 & - & - & $0.32 \rightarrow$ \\
\hline 24 & 21 & 母 & - & 0.32 & 46 & 20 & 母 & $\mathrm{HI}$ & - & $\leftarrow 0.005$ \\
\hline & & 兒 & - & 0.64 & 46 & 20 & 兒 & + & - & $\leftarrow 0.005$ \\
\hline 25 & 29 & 母 & - & $0.08 \rightarrow \leftarrow 0.16$ & 47 & 24 & 母 & - & - & 0.02 \\
\hline & & 兒 & - & $0.16 \rightarrow \leftarrow 0.32$ & $4 \pi$ & & 兒 & - & - & $0.02 \rightarrow$ \\
\hline 26 & 29 & 册 & - & $\leftarrow 0.005$ & 18 & 31 & 母 & - & - & $\leftarrow 0.16$ \\
\hline & & 兒 & - & 0.005 & 48 & & 兒 & - & - & $\leftarrow 0.32$ \\
\hline 27 & 30 & 母 & - & 1.28 & 40 & 46 & 母 & - & - & $0.16 \rightarrow$ \\
\hline & & 兒 & - & $1.28 \rightarrow \leftarrow 2.56$ & 49 & & 兒 & - & - & $\leftarrow 0.32$ \\
\hline 28 & 26 & 母 & - & 0.02 & 50 & 30 & 母 & $\mathrm{H}$ & - & $\leftarrow 0.005$ \\
\hline & 20 & 兒 & - & 0.04 & & & 兒 & \pm & - & $\leftarrow 0.005$ \\
\hline 29 & 35 & 母 & - & 0.16 & 51 & 21 & 母 & - & - & $0.02 \rightarrow$ \\
\hline & & 兒 & - & $0.16 \rightarrow \leftarrow 0.32$ & & & 兒 & - & - & $0.04 \rightarrow$ \\
\hline 30 & 24 & 母 & - & 0.16 & 52 & 20 & 母 & - & - & $0.16 \rightarrow$ \\
\hline & & 兒 & - & 0.32 & & & 兒 & - & - & $0.32 \rightarrow$ \\
\hline 31 & 24 & 母 & $\mathrm{H}$ & $\leftarrow 0.005$ & 53 & 28 & 母 & - & $\mathrm{HI}$ & 0.01 \\
\hline & & 兒 & - & $\leftarrow 0.005$ & & & 兒 & - & - & 0.02 \\
\hline 32 & 22 & 母 & $\mathrm{H}$ & $\leftarrow 0.005$ & 54 & 27 & 母 & - & $+t$ & $0.64 \rightarrow$ \\
\hline & & 兒 & - & $\leftarrow 0.005$ & & & 兒 & - & - & $1.28 \rightarrow$ \\
\hline 33 & 23 & 母 & - & $\leftarrow 0.005$ & 55 & 31 & 母 & - & - & $0.64 \rightarrow$ \\
\hline & & 兒 & - & 0.005 & & & 兒 & - & - & $0.64 \rightarrow$ \\
\hline 34 & 23 & 母 & - & 0.01 & 50 & 36 & 母 & - & + & $0.16 \rightarrow$ \\
\hline & & 兒 & - & 0.02 & 56 & 30 & 兒 & - & - & $0.32 \rightarrow$ \\
\hline & 28 & 母 & - & 0.08 & 57 & & 母 & - & H & $0.64 \rightarrow$ \\
\hline 35 & 28 & 兒 & - & 0.16 & 57 & 28 & 兒 & - & - & $1.28 \rightarrow$ \\
\hline & 29 & \# & $+t$ & $\leftarrow 0.0025$ & 58 & 28 & 母 & - & - & 0.32 \\
\hline & 29 & 兒 & -1 & $\leftarrow 0.0025$ & 5৪ & $2 \gamma$ & 兒 & - & - & 0.64 \\
\hline
\end{tabular}




\begin{tabular}{|c|c|c|c|c|c|c|c|c|c|c|c|}
\hline \multirow{2}{*}{59} & \multirow{2}{*}{34} & 母 & $=$ & $t+$ & $\leftarrow 0.32$ & \multirow{2}{*}{80} & \multirow{2}{*}{27} & 母 & Ht & - & $\leftarrow 0.005$ \\
\hline & & 兒 & - & - & $\leftarrow 0.32$ & & & 兒 & \pm & - & $\leftarrow 0.005$ \\
\hline \multirow{2}{*}{60} & \multirow{2}{*}{25} & 母 & - & - & 0.32 & \multirow{2}{*}{81} & \multirow{2}{*}{27} & 母 & - & - & $0.16 \rightarrow$ \\
\hline & & 兒 & - & - & 0.64 & & & 兒 & - & - & $0.16 \rightarrow$ \\
\hline \multirow{2}{*}{61} & \multirow{2}{*}{30} & 母 & - & - & $0.08 \rightarrow$ & \multirow{2}{*}{82} & \multirow{2}{*}{33} & 母 & - & H & $0.32 \rightarrow$ \\
\hline & & 兒 & - & - & $\leftarrow 0.16$ & & & 兒 & - & - & $0.32 \rightarrow$ \\
\hline \multirow{2}{*}{62} & \multirow{2}{*}{41} & 母 & - & + & 0.32 & \multirow{2}{*}{83} & \multirow{2}{*}{21} & 母 & $\mathrm{H}$ & - & $\leftarrow 0.005$ \\
\hline & & 兒 & - & - & 0.64 & & & 兒 & - & - & $\leftarrow 0.005$ \\
\hline \multirow{2}{*}{63} & \multirow{2}{*}{25} & 母 & - & + & $0.16 \rightarrow$ & \multirow{2}{*}{84} & \multirow{2}{*}{27} & 母 & H & $+t$ & $\leftarrow 0.005$ \\
\hline & & 兒 & - & - & $0.16 \rightarrow$ & & & 兒 & \pm & - & $\leftarrow 0.005$ \\
\hline \multirow{2}{*}{64} & \multirow{2}{*}{38} & 母 & - & - & $0.04 \rightarrow$ & 85 & 27 & 母 & - & + & 0.16 \\
\hline & & 兒 & - & - & $0.08 \rightarrow$ & & $\alpha \gamma$ & 兒 & - & - & $0.16 \rightarrow$ \\
\hline 65 & 31 & 母 & - & + & $\leftarrow 0.02$ & 86 & 24 & 母 & - & $t+$ & 0.32 \\
\hline & & 兒 & - & - & $\leftarrow 0.02$ & & & 兒 & - & - & 0.64 \\
\hline 66 & 25 & 母 & - & - & $0.32 \rightarrow$ & 87 & 36 & 母 & + & \pm & 0.32 \\
\hline 60 & ZJ & 兒 & - & - & $0.64 \rightarrow$ & & & 兒 & - & $=$ & 0.64 \\
\hline 67 & 22 & 母 & - & \pm & $\leftarrow 0.64$ & 88 & 29 & 母 & - & - & $\leftarrow 0.005$ \\
\hline & & 兒 & - & - & $0.64 \rightarrow$ & & & 兒 & - & - & 0.01 \\
\hline 68 & 27 & 册 & - & $+t$ & $\leftarrow 0.16$ & 89 & 27 & 母 & - & $+t$ & 0.02 \\
\hline & & 兒 & - & - & 0.16 & 0. & 21 & 兒 & - & - & 0.04 \\
\hline 69 & 26 & 母 & - & - & 0.16 & 90 & 19 & 母 & - & - & \\
\hline & & 兒 & - & - & $0.32 \rightarrow$ & & & 兒 & - & - & 0.04 \\
\hline 70 & 29 & 母 & - & $t+$ & $1.28 \rightarrow$ & 91 & 35 & 母 & - & $+t$ & \\
\hline & & 兒 & - & - & $1.28 \rightarrow$ & & 30 & 兒 & - & - & 0.16 \\
\hline & 27 & 母 & - & - & 0.04 & 92 & 23 & 母 & $+t$ & - & \\
\hline 71 & $2 \gamma$ & 兒 & - & - & 0.08 & 92 & $2 J$ & 兒 & - & - & $\leftarrow 0.005$ \\
\hline 72 & 26 & 母 & - & - & $0.16 \rightarrow$ & 93 & 28 & 母 & - & + & \\
\hline 14 & 20 & 兒 & - & - & $0.32 \rightarrow$ & 90 & 20 & 兒 & - & - & $0.08 \rightarrow$ \\
\hline 73 & 26 & 母 & - & - & $0.16 \rightarrow$ & 94 & 21 & 母 & $+t$ & - & \\
\hline 75 & 20 & 兒 & - & - & $0.32 \rightarrow$ & & & 兒 & \pm & - & $\leftarrow 0.005$ \\
\hline 74. & 25 & 母 & - & - & $0.02 \rightarrow$ & 95 & 24 & 母 & - & - & $0.08 \rightarrow$ \\
\hline & & 兒 & - & - & $0.04 \rightarrow$ & & & 兒 & - & - & \\
\hline 75 & 28 & 母 & - & - & 0.08 & 96 & 27 & 母 & - & + & \\
\hline & & 兒 & $=$ & - & 0.16 & 90 & $\alpha \delta$ & 兒 & - & - & 1.28 \\
\hline 76 & 23 & 母 & $=$ & - & 0.08 & 97 & 27 & 母 & - & + & \\
\hline & & 兒 & - & - & $0.08 \rightarrow$ & 90 & $2 t$ & 兒 & - & - & $0.64 \rightarrow$ \\
\hline 77 & 25 & 母 & - & - & 0.005 & 98 & 21 & 母 & - & - & \\
\hline & & 兒 & - & - & 0.005 & & $z \perp$ & 兒 & - & - & $0.16 \rightarrow$ \\
\hline 781 & 19 & 母 & - & - & 0.16 & 99 & 26 & 母 & - & - & \\
\hline 18 & & 兒 & $=$ & - & 0.32 & 99 & $2 b$ & 兒 & - & - & $0.32 \rightarrow$ \\
\hline 79 & 28 & 母 & \pm & - & $\leftarrow 0.005$ & 100 & 18 & 母 & 世 & - & \\
\hline 10 & 60 & 兒 & - & - & $\leftarrow 0.005$ & & & 兒 & - & - & $\leftarrow 0.005$ \\
\hline
\end{tabular}




\section{第二章 乳兒ニ於ケル「ショク」反應}

第 2 表二示ス如ク出生時像メ其ノ血液中ノ抗毒素量き測定シ「ショク」反礁き检シ置 キタル乳兒 66 例二就テ. 其ノ後再ビ「シック」反應き檢シタル二. 出生時ノ抗毒素量 0.005 單位以下ノモノニテモ本反應陽性トナルニ八生後 6 ケ月チ要スルチ認メタリ. 又出生時比較的多量ノ抗毒素尹有シタリシ乳兒ニアリテハ. 生後 8 ケ月二至りテ其， 一部ガ「ショク」反應陽性キ示ステ認ム。斯ノ如ク新產兒ノミナラズ乳兒ニ於テモ生後 約 6 ケ月間八其ノ抗素素保有ノ有無ニ關セズ「シック」反應ハ陰性トナルモノナリ。又 6 ケ月以後ト雖モ本反應八比較的出現シ難ク生後 1 ケ年ニシテ始メテ總テガ陽性トナ ルモ,、如シ。從ツテ孚兒二於テモ亦「シック」反應八抗毒素量檢定ノ尺度タリ得ザル モノナリ。

\begin{tabular}{|c|c|c|c|c|c|c|c|c|c|c|c|c|c|c|c|c|}
\hline \multirow{2}{*}{ 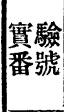 } & \multirow{2}{*}{$\begin{array}{l}\text { 姓 } \\
\text { 番號 }\end{array}$} & \multirow{2}{*}{ 姓名 } & \multirow{2}{*}{$\mid \begin{array}{l}\text { 分婏 時素量 } \\
\text { 量素 }\end{array}$} & \multirow{2}{*}{$\begin{array}{l}\text { 分晩時 } \\
\text { 反涉》 } \\
\text { 反應 } \\
\end{array}$} & \multicolumn{12}{|c|}{ 生 後「シック」反應 } \\
\hline & & & & & $\begin{array}{l}1 \text { ク } \\
\text { 月 }\end{array}$ & $\begin{array}{l}22 \text { ケ } \\
\text { 月 }\end{array}$ & $l_{13}^{3 \text { ケ }}$ & $\mid \begin{array}{l}4 . \text { ヶ } \\
\text { 月 }\end{array}$ & $\begin{array}{l}5 \text { ク } \\
19\end{array}$ & $\begin{array}{l}6 \text { म } \\
\text { 月 }\end{array}$ & $\left.\right|_{\text {月 }} ^{7}$ & $\mid \begin{array}{l}8 \text { ' } \\
\text { 月 }\end{array}$ & $\mid \begin{array}{l}9 \text { ヶ } \\
\text { 月 }\end{array}$ & \begin{tabular}{|l|}
10 ケ \\
月
\end{tabular} & $\begin{array}{l}11 \text { 万 } \\
\text { 月 }\end{array}$ & $\begin{array}{l}12 \text { 万 } \\
\text { 月 }\end{array}$ \\
\hline 1 & & & & & & & & & & & & & & & & 1 \\
\hline 2 & & & & & & & & & & & & & & & & + \\
\hline 3 & 1 & & 0.8 & - & & & & & & & & & - & & & \\
\hline 4 & 2 & & $\begin{array}{c}0.02 \\
\downarrow\end{array}$ & - & & & & & & & & & + & & & \\
\hline 5 & 3 & & $\begin{array}{c}0.02 \\
\downarrow\end{array}$ & - & & & & & & & & & + & & & \\
\hline 6 & 5 & & 0.1 & - & & & & & & & & & - & & & \\
\hline 7 & 7 & & 0.02 & - & & & & & & & & & - & & & \\
\hline 8 & 9 & & 0.4 & - & & & & & & & & & - & & & \\
\hline 9 & 6 & & $\begin{array}{c}0.02 \\
\downarrow\end{array}$ & - & & - & & & & & & & & & & \\
\hline 10 & 10 & & $\begin{array}{c}0.02 \\
\downarrow\end{array}$ & - & & & & & & & & & + & & & \\
\hline 11 & 11 & & 0.04 & - & & & & & & & & & - & & & \\
\hline 12 & 13 & & 0.02 & - & & \pm & & & & & & & & & & \\
\hline 13 & 15 & & 0.16 & - & & & & & & & & + & & & & \\
\hline 14 & 16 & & 0.32 & - & & & & & & & & - & & & & \\
\hline 15 & 20 & & 0.16 & - & & & & & & & & + & & & & \\
\hline 16 & 24 & & 1.28 & - & & & & & & & & - & & & & \\
\hline 17 & 27 & & 1.28 & - & & & & & & & & - & & & & \\
\hline 18 & 29 & & 0.02 & - & & & & & & & & - & & & & \\
\hline 19 & 32 & & 0.64 & - & & & & & & & & - & & & & \\
\hline 20 & 35 & & 0.005 & - & & - & & - & & & & & & & & \\
\hline 21 & 40 & & $\mid<0.005$ & - & - & & & & & & & & & & 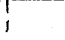 & \\
\hline
\end{tabular}




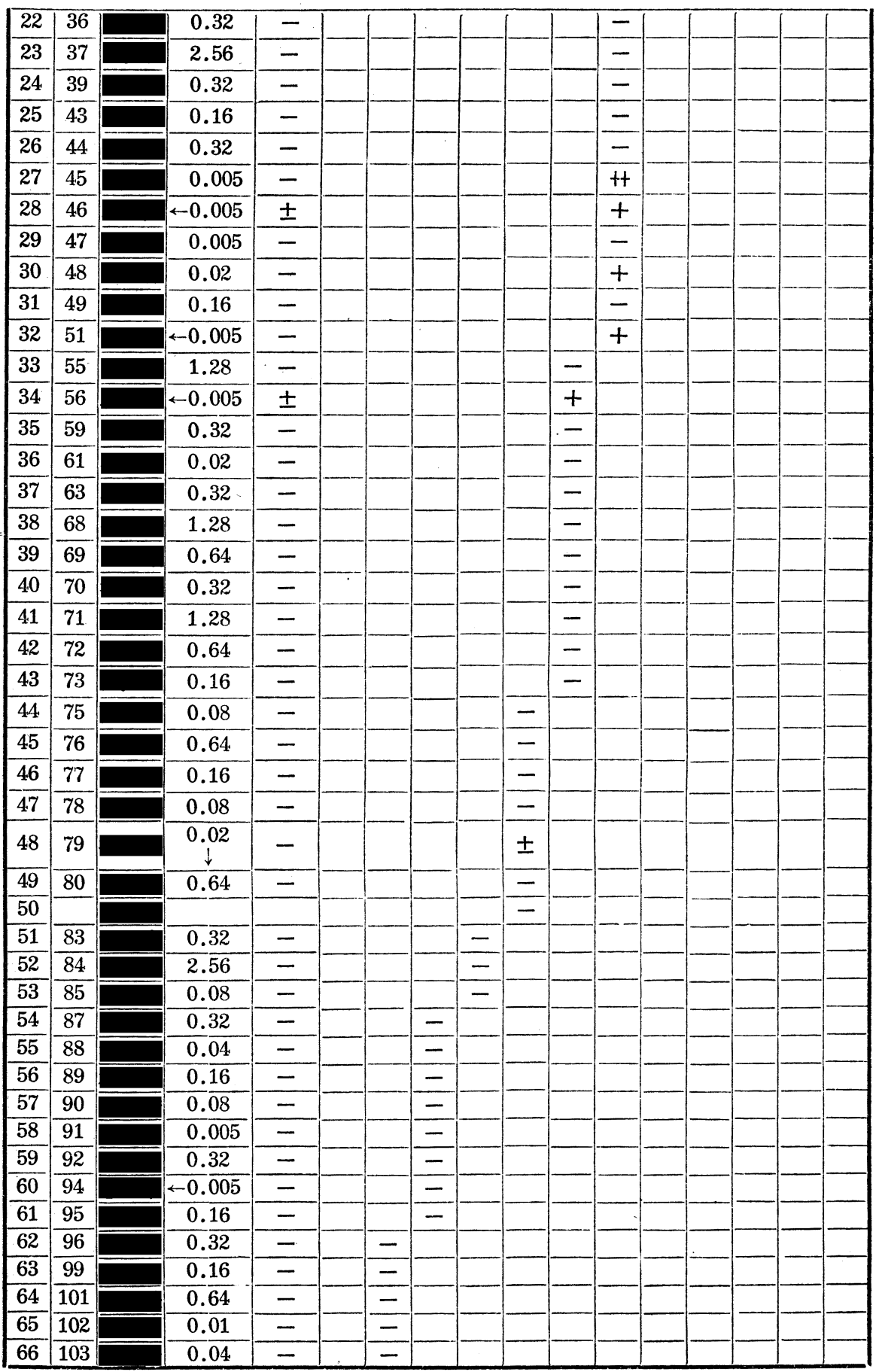


「シック」反應ノミナラズ．疑似反應モ亦生後 9 ケ月以內ノ乳兒ニ於テハ。總テ陰性 ナルキ見タルモノニシテ. 此點モ亦新產兒二酷似スルモノナリ。

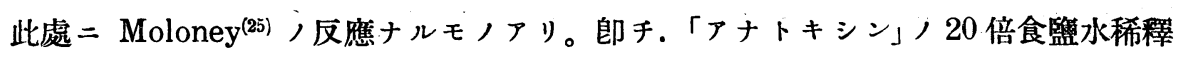
ヨ皮內二注射シ.ソノ反應發赤腫脹二從ツテ冕疫二使用スル「アナトキシン」ノ量タ加 減スルモノナリ。

乳兒二於テハ本反應モ亦悉ク陰性二終レリ。

斯クノ如ク乳兒モ亦新產兒卜同樣. 總テ, 皮膚反應二對シテ極メテ鈍感ナルモノニ シテ・此ノ等兒ノ「ショク」反應二對スル不感受性ガ. 本反應キ「ヂフテリー」罹患ノ有無 タ示ス確實ナル目標ト通信スル人々チシテ.「娒兒ニ八絕對先天性免疫アリ」ト誤り信 ゼシメシニハ非ズヤ。

\section{第三章 褯婦ニ於ヶル「シック」反應}

第 1 表二示ス如ク 100 例ノ褯婦二於テ.抗毒素量 0.005 單位以下ノモノ 23 例二對シ テ「シック」反應陽性ノモノ 17 例アリ。及ビ唯 1 例二於テ八抗毒素量 0.64 單位テ有スル 二拘ラズ陽性トナレルモノアリ. 都合 100 例中 18 例ノ陽性テ見タリ。郎チ裖婦二於テ モ亦比較的「シック」反應ハ現ハレ難キモノナルコトタ認ム。 又 Paradoxereaktion(矛 盾反應) チ現ハスモノモ極メテ少ク 100 例中唯 1 例:過ギザルモノナリ。

血液中八抗毒素量 0.005 單位以下ニシテ而モ「シック」反應陰性ナル 褯婦二於テ長期 二瓦りテ觀察タ行フ中或ル時期ノノチ「シック」反應ガ陽性二轉化スル如キコトハ無キ カ. 此, 點テ明カナラシメントシテ斯ル例二於テハ分婏後約牛年二瓦りテ「シック」反 應キ檢シタルモ遂ニ明カナル成績キ得ザリキ(第 3 表)。

第 3 表 產裖二於ケル「シック」反應/消長

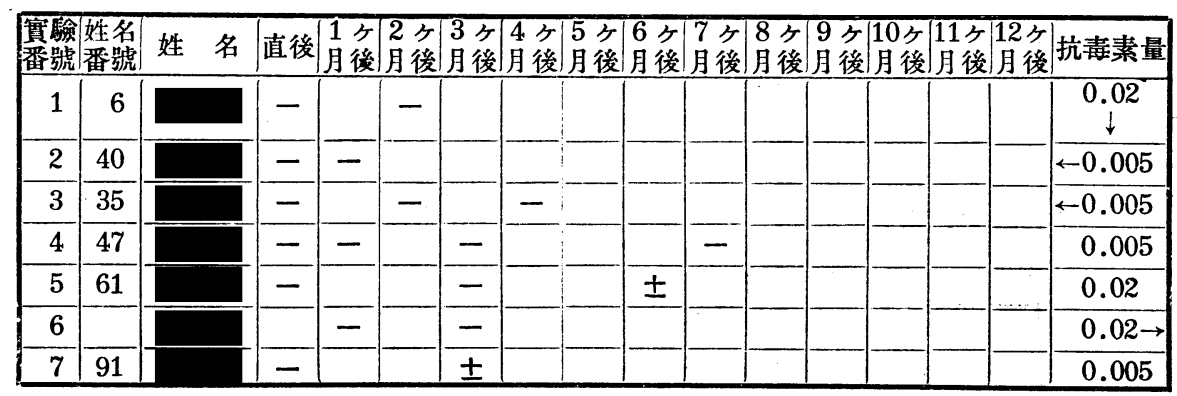

疑似反應八新產兒. 乳兒二於ケルト異ナリ 58 例中 21 例二えキ認メタリ。 


\section{第四古 妊婦ニ於ケル「シック」反應}

第 4 表二示ス如ク 42 例ノ妊婦二於テ其ノ血液中ノ抗毒素量き测定スルト同時二 「シック」反應キ檢シタルニ抗毒素保有量 0.005 單位以下モノ 15 例中本反應陽性ノモ ノ僅カ二 9 例ニシテ. 妊婦二於テモ亦. 褯婦二於ケルト同ジク. 抗毒素量 0.005 單位 以下ナルニ拘ラズ。「シャク」反應㓌性トナルモ, 、比較的多數ニ存スルチ知ルモノナ リ。更二又 Paradoxereaktion モ亦極メテ少ク 42 例中唯 1 例二於テ其ノ抗素素量 0.32 單位ニシテ「シック」反應陽性トナレルモノアルニ過ギズ。

疑似反應八 42 例中 14 例ニシテ裖婦ノ場合卜殆ンド一致ス。

更二「モロネ一」反應キ檢シタルニ㓡兒二於テハ 1 例ノ陽性キモ見ザリシニ妊婦二於

第 4 表＼cjkstart娃婦二於ヶル「シック」反應

\begin{tabular}{|c|c|c|c|c|c|c|c|}
\hline 妊㑐月數 & 番號 & 姓 名 & 年路 & $\mid \begin{array}{l}\text { 「シック } \\
\text { 反 }\end{array}$ & \begin{tabular}{ll}
\multirow{z}{*}{} & 似 \\
\end{tabular} & $\begin{array}{l}\text { 厄モロ } \\
\text { ホー } \\
\text { 反應 }\end{array}$ & $\begin{array}{l}\text { 血清中 } \\
\text { 抗瑇素量 }\end{array}$ \\
\hline \multirow{2}{*}{ S. II. M. } & 1 & & 28 & - & - & \pm & 0.32 \\
\hline & 2 & & 25 & & & & 0.64 \\
\hline \multirow{5}{*}{ S. 政. M. } & 3 & & 22 & - & H & \pm & +-0.005 \\
\hline & 4 & & 28 & - & \pm & + & $\leftarrow 0.005$ \\
\hline & 5 & & 27 & tt & - & H & $\leftarrow 0.005$ \\
\hline & 6 & & 29 & - & - & tt & 0.16 \\
\hline & 7 & & 21 & - & - & + & 0.16 \\
\hline \multirow{3}{*}{ S. V. M. } & 8 & & 28 & - & - & + & 0.16 \\
\hline & 9 & & 22 & - & - & H & $\leftarrow 0.005( \pm)$ \\
\hline & 10 & & 24 & - & - & - & 0.08 \\
\hline \multirow{7}{*}{ S. VI. M. } & 11 & & 27 & - & - & - & 0.08 \\
\hline & 12 & & 28 & iH & - & +1 & $\leftarrow 0.005$ \\
\hline & 13 & & 29 & W & - & - & $\leftarrow 0.005$ \\
\hline & 14 & & 29 & - & $\mathrm{HH}$ & $t+$ & 0.64 \\
\hline & 15 & & 30 & - & - & $\mathrm{HH}$ & $\leftarrow 0.005$ \\
\hline & 16 & & 24 & - & H & - & 0.04 \\
\hline & 17 & & 38 & - & $\mathrm{H}$ & - & 0.64 \\
\hline \multirow{4}{*}{ S. VII. M. } & 18 & & 27 & - & + & H & 0.16 \\
\hline & 19 & & 27 & - & \pm & t+ & 0.02 \\
\hline & 20 & & 22 & $H$ & - & - & $\leftarrow 0.005$ \\
\hline & 21 & & 26 & - & $t+$ & tt & 0.32 \\
\hline \multirow{5}{*}{ S. VII. M. } & 22 & & 30 & - & + & + & 0.32 \\
\hline & 23 & & 20 & - & $t+$ & - & $\leftarrow 0.005$ \\
\hline & 24 & & 30 & - & - & \pm & 0.64 \\
\hline & 25 & & 27 & $H$ & + & \pm & 0.32 \\
\hline & 26 & & 33 & - & - & + & 0.16 \\
\hline
\end{tabular}




\begin{tabular}{|c|c|c|c|c|c|c|}
\hline \multirow{6}{*}{ - } & 27 & 21 & $H$ & + & - & -0.005 \\
\hline & 28 & 23 & $t+$ & - & - & -0.005 \\
\hline & 29 & 27 & - & - & - & 1.28 \\
\hline & 30 & 27 & - & - & - & 0.16 \\
\hline & 31 & 29 & - & tt & + & 0.32 \\
\hline & 32 & 26 & - & + & - & 0.32 \\
\hline \multirow[t]{7}{*}{ S. IX. M. } & 33 & 23 & - & - & H & $\leftarrow 0.005$ \\
\hline & 34 . & 23 & - & - & + & 0.08 \\
\hline & 35 & 29 & - & - & - & 0.08 \\
\hline & 36 & 28 & - & H & $\mathrm{m}$ & 0.32 \\
\hline & 37 & 31 & - & \pm & H & 0.04 \\
\hline & 38 & 34 & $\mathrm{H}$ & \pm & \pm & $\leftarrow 0.005$ \\
\hline & 39 & 24 & - & - & - & 1.28 \\
\hline S. X. M. & 40 & 29 & m & - & - & $\leftarrow 0.005$ \\
\hline S. VII. M. & 41 & 29 & - & - & - & 0.08 \\
\hline S. IX. M. & 42 & 25 & $+t$ & $t$ & \pm & $\leftarrow 0.005$ \\
\hline
\end{tabular}

テハ 42 例中 19 例二陽性キ認メタリ。

\section{第五章 對照 健常婦人二於ケル「シック」反應}

上述セル如ク．新產兒.乳兒ノてナラズ．妊婦及ビ裖婦ニ於テモ「シック」反應ガ現八 レ難ク更二 Paradoxereaktion キ見ルコト極メテ少キキ認メタルモ. 先人が健常成人 二於テ行へル「シック」反應，成績タ見ル二.其ノ抗毒素量 0.005 單位以下ナルモ八八勿 論 0.005 單位以上ノモノニテモ「シック」反應陽性トナルモノ(即チ Paradoxereaktion ヨ示スモノ)年齡卜共二增加スルモノ、如シ。然ラバ余等ノ成績八或八實驗方法ノ缺 陷ニョル誤差ナリヤ或ハ又. 先人, 交獻二末ダ胃ザル所/裖婦及ビ妊婦二於ケル特異 八現象ナリヤ。之フ確ムルタメ二余等八約同年齡, 健常看護婦二就テ抗毒素量，测定 キ行フト同時ニ「シック」反應. 及ビ「モロネ一」反應キ檢シタルニ第 5 表二見ル如ク 104 例中抗毒素量 0.005 單位以下ノモノ 8 例アリテ，是等八悉ク「シック」反應モ陽性ナリ キ. 更二又. 抗毒素 0.005 單位以上ニシテ而モ「シック」反應陽性ナルモノ (Paradoxereaktion キ示スモノ) 9 例ノ多數二昇レリ。此ノ結果ハ明カ二先人ガ. 健常成人二就 テナセル結果ト一致スルモノニシテ從ツテ余等ノ裖婦及ビ妊婦二於ケル成績八。未ダ 先人ノ業績二見ザル所ノ褯婦及ビ妊婦二特異ナル一現象き發見セルモノナリ。

余等, 健常例二於テ抗毒素量 0.005 單位以下,モノ比較的少キ八. 是等ガ皆看護媂 ニシテ「ヂフテリー」ニ接スル機會ガ多ク潛性, 免疫テ躰二獲得セルタメナルベシ。 疑似反應二關シテハ 52 例中 20 例陽性二シテ.之八裖婦及ビ弤婦ト殆ンド一致スル 
第 5 表健常婦人ニ於ヶル「シック」反應

\begin{tabular}{|c|c|c|c|c|c|c|c|c|c|c|c|c|c|c|c|}
\hline 號 & 名 & $\begin{array}{l}\text { 年 } \\
\text { 踰 }\end{array}$ & 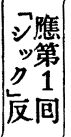 & $\begin{array}{l}\text { 籎 } \\
\text { 應 } \\
\text { 焦 }\end{array}$ & $\begin{array}{l}\text { モ反 } \\
\text { 口 } \\
\text { 衣應 }\end{array}$ & $\begin{array}{l}\text { 血抗 } \\
\text { 清素 } \\
\text { 中量 }\end{array}$ & 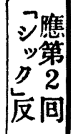 & $\begin{array}{l}\text { 番 } \\
\text { 號 }\end{array}$ & 名 & $\begin{array}{l}\text { 年 } \\
\text { 龄 }\end{array}$ & 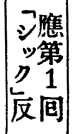 & 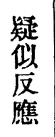 & 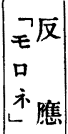 & $\begin{array}{l}\text { 血抗 } \\
\text { 清畫 } \\
\text { 中量 }\end{array}$ & 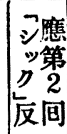 \\
\hline 1 & & 23 & - & & & & & 39 & & 19 & $\mathrm{HH}$ & & & $\leftarrow 0.005$ & \\
\hline 2 & & 16 & - & & & & & 40 & & 21 & - & & & & \\
\hline 3 & & 17 & - & & & & & 41 & & 23 & - & & & & \\
\hline 4 & & 16 & - & & & & & 42 & & 21 & - & & & & \\
\hline 5 & & 16 & - & & & & & 43 & & 24 & + & & & 0.16 以上 & $=1$ \\
\hline 6 & & 21 & \pm & & & 0.16 以上 & & 44 & & 25 & - & & & & \\
\hline 7 & & 17 & \pm & & & 0.16 以上 & & 45 & & 20 & - & & & & \\
\hline 8 & & 20 & - & & & & & 46 & & 20 & - & & & & \\
\hline 9 & & 17 & - & & & & & 47 & & 32 & - & & & & \\
\hline 10 & & 18 & t+ & & & 0.16 以上 & - & 48 & & 18 & - & & & & \\
\hline 11 & & 18 & \pm & & & 0.16 以上 & & 49 & & 26 & - & & & & \\
\hline 12 & & 21 & - & & & & & 50 & & 21 & - & & & & \\
\hline 13 & & 17 & - & & & & & 51 & & 26 & - & & & & \\
\hline 14 & & 16 & - & & & & & 52 & & 24 & - & & & & \\
\hline 15 & & 16 & - & & & 0.16 以上 & & 53 & & 26 & - & $\mathrm{WH}$ & t+ & & \\
\hline 16 & & 16 & - & & & & & 54 & & 29 & - & - & + & & \\
\hline 17 & & 17 & + & & & 0.16 以上 & - & 55 & & 23 & - & - & + & & \\
\hline 18 & & 18 & \pm & & & 0.16 以上 & & 56 & & 25 & - & - & + & & \\
\hline 19 & & 19 & - & & & & & 57 & & 31 & - & - & \pm & & \\
\hline 20 & & 17 & - & & & & & 58 & & 29 & - & - & + & & \\
\hline 21 & & 20 & - & & & & 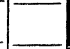 & 59 & & 24 & - & - & + & & \\
\hline 22 & & 21 & H & & & 0.16 以上 & + & 60 & & 22 & - & - & - & & \\
\hline 23 & & 17 & - & & & & & 61 & & 23 & - & - & + & & \\
\hline 24 & & 18 & - & & & & & 62 & & 20 & - & - & + & & \\
\hline 25 & & 16 & + & & & $\leftarrow 0.005$ & & 63 & & 19 & - & - & - & & \\
\hline 26 & & 16 & $t+$ & & & & & 64 & & 23 & - & - & - & & \\
\hline 27 & & 20 & - & & & & & 65 & & 26 & + & - & - & & \\
\hline 28 & & 18 & + & & & 0.16 以上 & + & 66 & & 22 & - & - & - & & \\
\hline 29 & & 16 & - & & & & & 67 & & 27 & - & + & - & & \\
\hline 30 & & 16 & - & & & & & 68 & & 24 & - & - & - & & \\
\hline 31 & & 16 & - & & & & & 69 & & 24 & - & - & + & & \\
\hline 32 & & 24 & - & & & & & 70 & & 24 & - & tt & - & & \\
\hline 33 & & 25 & - & & & & & 71 & & 22 & - & H & - & & \\
\hline 34 & & 22 & $\mathrm{H}$ & & & $\leftarrow 0.005$ & & 72 & & 24 & - & - & - & & \\
\hline 35 & & 20 & - & & & & & 73 & & 21 & + & - & - & & \\
\hline 36 & & 20 & - & & & & & 74 & & 25 & - & $\mathrm{m}$ & tt & & \\
\hline 37 & & 16 & - & & & & & 75 & & 23 & - & $\mathrm{H}$ & + & & \\
\hline 38 & & 19 & - & HI & & $\mid 0.16$ 以上 & & 76 & & 21 & $\mathrm{ml}$ & H & - & $\leftarrow<0.005$ & \\
\hline
\end{tabular}




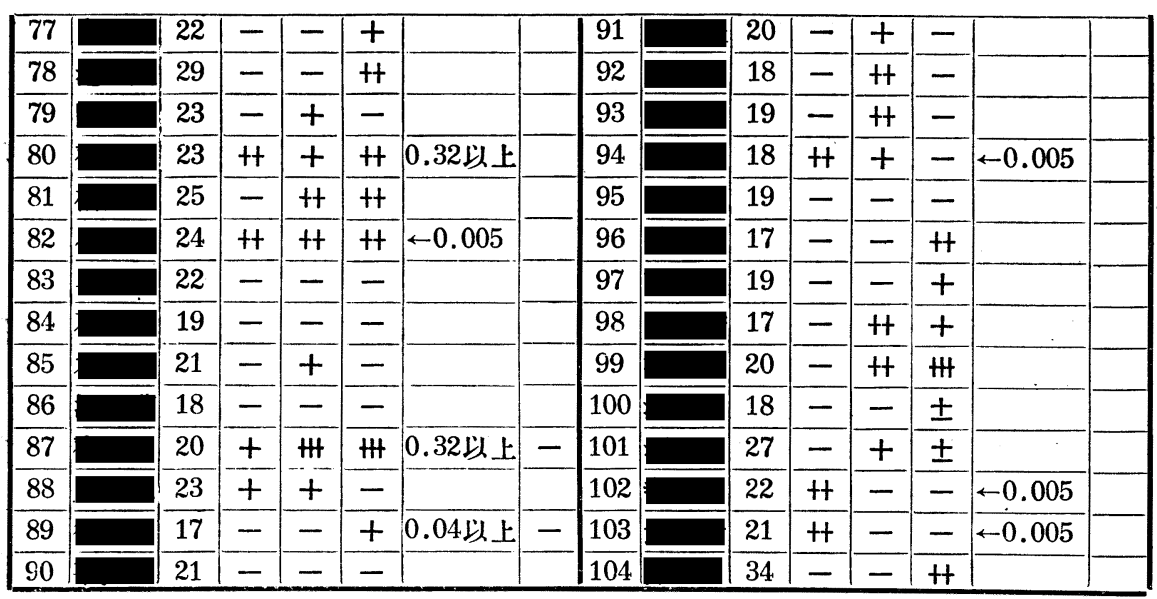

モノナリ。

又「モロネ一」反應モ亦 52 例中 23 例陽性ニシテ之亦娃婦，場合ト一致スルモ；ナ リ。

\section{第三編ノ總括}

1） a）新產兒二於テハ血液中ノ抗毒素量ノ多少ニ拘ラズ.「シック」反應ハ殆ンド總 テ陰性二現ハル、モノナリ。

b)「シック」反應ノえナラズ. 疑似反應モ亦全然出現セズ。

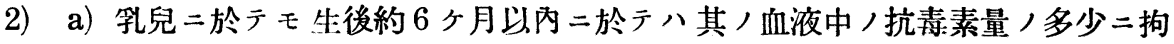
ラズ「シック」反應ハ殆ンド陰性トナルモノナリ。

b）疑似反應モ亦全ク陰性トナルモノナリ。

c)「モロネ一」反應モ悉ク陰性ナリ。

3） a）褯㷌二於テモ抗毒素量 0.005 單位以下ナルニ拘ラズ.「シック」反應陰性ナル ガ如キモノ比較的多ク健康成人ト異ナルモノナリ。

b) 抗毒素き多量二有スルニ拘ラズ「シック」陽性トナルガ如キモノ郎チ Paradoxere aktion キ示スモノキ見ルコト極メテ少ク之亦健康成人ノ場合ト異ナルモノナリ。

c) 疑似反應八健常成人二於ケルト同樣約全例 $1 / 3=之$ 認ム。

4） a）妊婦二於ケル成績モ亦全然裖婦ニ一致スルモノニシテ.

師チ a)「シック」反應ハ抗毒素量ノ多少ニ拘ラズ. 陰性トナリ易ク. 健常成人ノ場 合ト異ナル。

b) Paradoxereaktion チ見ルコト少ク之又. 健常成人ト趣キ異ニス。 
c) 疑似反應ハ全例ノ約 $1 / 3=$ 現ハレ. 健常成人二等シク新產兒及ビ乳兒卜異ナルモ イナリ。

d)「モロネーノ反應モ亦全例ノ約牛數二發現スルモノニシテ此ノ點モ亦. 健常成人 ト等シク・新產兒及ビ乳兒二背反スルモノナリ。

斯ノ如ク、裖婦及ビ妊㷌ハ「シ.ク」反應及ビ Paradoxereaktion 出現ノ狀態二關シ テハ新產兒. 乳兒二近ク疑似反應及ビ「モロネー」反應二關シテハ健常成人二近キ位置 キトルモノナリ。

次ニ「シック」反應ト疑似反應ト, 關係キ見ルニ第 6 表二示ス如ク 褯婦二於テハ兩者 八相反スルガ如キ事賽キ見ル。師チ。「シック」反應陽性ノモノ二於テハ疑似反應ハ多ク 陰性ナル如キキ認ム。然ル二. 弤婦二於テ八兩者ノ關係不定ナリ。郎チ。「シック」反應 陽性ノモノニ於テ・疑似反應陽性ノモノト陰性ノモノ卜ノ割合八略?同樣ナリ。然ル 二又. 健常婦人二於テハ上記ノモノト八異ナリ兩者相站行スルガ如シ。郎チ・「シック」 反應陽性ノモノ二於テ八疑似反應陽性ノモノ多シ。

此ノ成績八例數未ダ僅少ナルキ以テ確定的ニハ非ザルモ從來， 疑似反應八兌疫 得タルモノニヨリ多ク現ハルトノ見解ト多少異ナルモノニシテヌ裖婦. 弤媂. 健常婦 人ノ間二差異キ認ムル等興味アル成績ナリ。

第 6 表「シック,反隹ト疑似反憵卜, 關係

\begin{tabular}{|c|c|c|c|c|c|c|c|c|c|c|}
\hline & \multicolumn{2}{|c|}{ 裖 } & 㜭 & \multicolumn{2}{|c|}{ 娃 } & 婦 & \multicolumn{3}{|c|}{ 健 常 婦 人 } \\
\hline & & \multicolumn{2}{|c|}{ 疑似反應 } & \multirow{2}{*}{ 計 } & 疑 & 似 & \multirow{2}{*}{ 計 } & 凝 & 似 & \multirow{2}{*}{ 計 } \\
\hline & & + & - & & + & - & & + & - & \\
\hline \multirow{2}{*}{ シック } & + & 1 & 7 & 8 & 3 & 7 & 10 & 6 & 4 & 10 \\
\hline & - & 20 & 30 & 50 & 11 & 20 & 31 & 15 & 27 & 42 \\
\hline \multicolumn{2}{|c|}{ 計 } & 21 & 37 & 58 & 14 & 27 & 41 & 21 & 31 & 52 \\
\hline
\end{tabular}

次ニ「シック」反應ト「モロネー」反應トノ關係チ見ルニ.第 7 表二示ス如ク弤婦二於テ モ健常婦人二於テモ此, 兩者ノ反應八相反スルモノ、如シ。郎チ「シック」反應陽性, モノニ於テハ「モロネー」反應ハ多ク陰性トナルモノナリ。

第 7 表「「シック」反礁ト「モロネー」反礁トノ關係

\begin{tabular}{|c|c|c|c|c|c|c|c|}
\hline & \multicolumn{2}{|c|}{ 妊 } & 嗀 & & 常 & 人 \\
\hline & & \multicolumn{2}{|c|}{ 「モロネ一」 } & \multirow{2}{*}{ 計 } & \multicolumn{2}{|c|}{ 「モロネー1 } & \multirow{2}{*}{ 計 } \\
\hline & & + & - & & + & - & \\
\hline \multirow{2}{*}{ ג } & + & 2 & 8 & 10 & 3 & 7 & 10 \\
\hline & - & 17 & 14 & 31 & 20 & 22 & 42 \\
\hline & & 19 & 22 & 41 & 23 & 29 & 52 \\
\hline
\end{tabular}


次二又. 疑似反應ト「モロネ一」反應卜ノ關係キ見ルニ第 8 表二示ス如ク弤婦二於テ モ健常婦人二於テモ此, 兩者, 關係八不定ナルモ, 、如シ。郎千疑似反應陽性ノモ， ニ於テ「モロネー」反應八約同樣ノ割合二出現シ。不「ロネ一」反應陽性ノ側ヨリ見ル モ. 疑似反應八大體同樣，割合二現ハル、モノナリ。郎チ此ノ兩反應八獨立七ル反應 ニシテ互二相關係スル所ナキモ, 、如シ。

第 8 表疑似反雇卜「モロネー」反應卜，關係

\begin{tabular}{|c|c|c|c|c|c|c|c|}
\hline & \multicolumn{2}{|c|}{ 娃 } & 藍 & \multicolumn{3}{|c|}{ 健 常 媼 人 } \\
\hline & & \multicolumn{2}{|c|}{ 「モロ衣一」 } & \multirow{2}{*}{ 計 } & \multicolumn{2}{|c|}{ 「モ口亦一」 } & \multirow{2}{*}{ 計 } \\
\hline & & + & - & & + & - & \\
\hline \multirow{2}{*}{$\begin{array}{l}\text { 疑似 } \\
\text { 反礁 }\end{array}$} & $t$ & 6 & 8 & 14 & 9 & 12 & 21 \\
\hline & - & 13 & 14 & 27 & 14 & 17 & 31 \\
\hline \multicolumn{2}{|c|}{ 計 } & 19 & 22 & 41 & 23 & 29 & 52 \\
\hline
\end{tabular}

最後二新產兒及ビ孚兒二於テ血液中ノ抗毒素量, 低キ場合郎チ０.005 單位以下二 テモ「シック」反應ハ陰性トナリ，又疑似反應。「モロれー」反應モ全ク發現セザルッ何 故ナリヤ。更二又妊婦及ビ褯婦二於テモ健常婦人卜異ナリ。「ショタ反應八其ノ抗青素 保有量，低ク 0.005 單位以下ノ場合二モ發現七ザルモノアルハ何故ナリヤ。

新花兒. 乳兒二於ケル此ノ現象二關シテ Kuttner \& Ratner ハ「シック」應二際シ

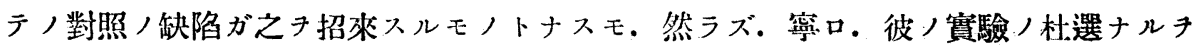
知ルノ 氵. Gröer \& Kassowitz 八新產兒及ビ乳兒二於テハ Receptorenmangel 二 ヨル自然免疫ノ存スルモノナルコト，及ビ是等二於テ八皮膚二炎症發生機構が缺乏七 ルコトノニッノ假說ニヨリテえキ說明セントス。

余等ノ成績二於テ見ル如ク. 新產兒及ビ乳兒二於テハ「ショク」反應ノてナラズ. 加熱 破壞亚素ニヨル皮膚反應(疑似反應)及ビ「アナトキシン」ニヨル皮膚反應(「モロネ一」 反應)モ亦發現セザルモノニシテ此，點ヨリ見レバ. 新產兒及ビ乳兒二八確力:皮雐， 炎症發生機構ノ缺乏チ考へ得ベキモ. 更二是等體中ノ「アレルゲン」/缺乏セル事實子 モ亦想起スベキニ非ズヤ。然レドモ妊婦及ビ褯婦ニ於テ八，加熱破壞毒素二ヨル反應 (擬似反應)及ビ「モロネ一」反應八普通二發現スルニ拘ハラズ「シック」反應ノ發現率， 低下七ル事實. 及ビ第6.7表二示セル事實ヨリ見レバ「シック」反應八決シテ疑似反 應及ビ「モロネー」反應等ト同一二取り扱つべキモノニ非ズシテ・從ッテ Gröer \& Kassowitz ノ云つ如キ簡單ナル假說ノミチ以ツテ說明シ得ルモノニ非ザルキ知ル。 余等八今此ノ本態二關スル研究二從事中ニシテ項キ改メテ發表スル所アルベシ。 